\author{
mgr Wojciech KRÓWCZYŃSKI \\ doktorant Wydziału Zarządzania i Komunikacji Społecznej, Uniwersytet Jagielloński \\ e-mail: wojciech.krowczynski@doctoral.uj.edu.pl
}

DOI: $10.15290 /$ ose.2017.02.86.13

\title{
WYBÓR FORMY KOORDYNACJI (GOVERNANCE MODE) DLA GOSPODAROWANIA DANYMI OSOBOWYMI PACJENTÓW W PODMIOTACH LECZNICZYCH
}

\begin{abstract}
Streszczenie
Celem artykułu jest przedstawienie z perspektywy ekonomii kosztów transakcji (EKT) uwarunkowań wyboru dotyczącego formy koordynacji (governance mode) dla gospodarowania danymi osobowymi pacjentów w podmiotach leczniczych. Działalność w zakresie przetwarzania i ochrony danych osobowych pacjentów stanowi istotny obszar gospodarowania w podmiotach leczniczych, zarówno ze względu na potrzebę zapewnienia wysokich standardów, jak i znaczne koszty: kontraktowania, nadzoru i utrzymania odpowiedniej infrastruktury materialnej. Podmioty lecznicze wykorzystują zróżnicowane sposoby realizacji tej działalności - od kontraktów rynkowych, przez umowy długoterminowe, aż po internalizację w ramach swoich struktur. Zdarza się jednak, że te alokacyjne wybory nie są efektywne, w równej mierze pod względem standardów bezpieczeństwa danych, jak i ponoszonych kosztów. W artykule, według założeń EKT, poddano interpretacji problem sposobu realizacji gospodarowania danymi osobowymi. W świetle tej teorii zaprezentowano istotę form koordynacji i determinanty ich wyboru. Następnie zanalizowano stosowane w podmiotach leczniczych formy koordynacji i ich determinanty, stwierdzając częściową niezgodność tych rozwiązań z ustaleniami EKT. W podsumowaniu sformułowano wnioski dotyczące metodyki dalszych badań i praktyki w zakresie wyboru formy alokacji dla gospodarowania danymi pacjentów w analizowanym sektorze.
\end{abstract}

Słowa kluczowe: podmiot leczniczy, dane osobowe, ekonomia kosztów transakcji, forma koordynacji

\section{CHOICE OF GOVERNANCE MODE FOR PROCESSING AND PROTECTING PATIENTS' PERSONAL DATA IN HEALTHCARE CENTRES}

\section{Summary}

The aim of the paper is to present the conditions regarding the choice of governance mode for processing and protection of patients' personal data in healthcare centres from the perspective of transaction cost economics (TCE). Processing and protection of patients' personal data is an important area of the economics of healthcare centres, due to the need to ensure high-quality standards and because of significant costs of contracting, coordinating, and maintaining adequate physical infrastructure. Healthcare centres adopt a variety of modes to implement this activity: market contracts, long-term contracts, and hierarchy (internalization) methods. The efficiency of these allocation choices is sometimes low, considering both the accomplished standards and incurred costs. In the paper, the problem of how to implement activities in the area of processing and protecting personal data is discussed in the light of TCE. Based on this theory, the paper discusses the particular governance modes and the motivation 
behind their choice. Further, the forms of governance and their determinants in healthcare centres are analyzed, and partial inconsistency of these solutions with the theoretical assumptions of TCE is revealed. The concluding section provides recommendations as to further methodology of research in this area together with practical implications.

Key words: healthcare centre, personal data, transaction cost economics, governance form

JEL: D02, D23, L25

\section{Wstęp}

Podmioty lecznicze ${ }^{1}$ podlegają wyzwaniu jakości usługi medycznej przy możliwie efektywnym gospodarowaniu [Nojszewska, 2011; Suchecka, 2010]. Poziom usługi medycznej dotyczy nie tylko wykonanego świadczenia w aspekcie zdrowotnym, lecz również poszanowania godności i dotrzymania tajemnicy lekarskiej. W świetle art. 40 ust. 1 Ustawy z dnia 5 grudnia 1996 roku o zawodach lekarza i lekarza dentysty (Dz. U. 1997, Nr 28, poz. 152 z późn. zm.), tajemnica lekarska jest ujmowana jako obowiązek lekarza do zachowania $\mathrm{w}$ tajemnicy informacji dotyczących pacjenta, a uzyskanych $\mathrm{w}$ związku $\mathrm{z}$ wykonywaniem zawodu.

Działalność w zakresie przetwarzania i ochrony danych osobowych pacjentów obecnie nabiera szczególnego znaczenia z uwagi na postępująca kompleksową informatyzację służby zdrowia, prowadzona w ramach unijnego projektu przez Centrum Systemów Informatycznych Ochrony Zdrowia. Zgodnie z art. 56 Ustany z dnia 28 kwietnia 2011 roku o systemie informacii w ochronie zdrowia (Dz. U. 2011, Nr 113, poz. 657 z późn. zm.), dokumentacja medyczna sporządzona do 31 grudnia 2017 roku może być prowadzona zarówno w formie elektronicznej, jak i papierowej. Po tym terminie, będzie obowiązywać jedynie dokumentacja elektroniczna. W ten sposób przetwarzanie i ochrona danych osobowych stają się coraz ważniejszym obszarem gospodarowania podmiotów leczniczych.

Działalność ta jest skierowana w stronę realizacji istotnych potrzeb związanych z: pozyskiwaniem, wykorzystywaniem i zapewnieniem poufności danych pacjentów. Jednocześnie powoduje ona znaczne koszty wynikające z kontraktowania i nadzoru nad tworzeniem i utrzymaniem infrastruktury informatycznej. W sektorze podmiotów leczniczych gospodarowanie danymi osobowymi pacjentów jest zarówno zarówno poprzez kontrakty rynkowe, jak i umowy długoterminowe czy internalizację działań w ramach danego podmiotu. Zdarza się jednak, że zróżnicowaniu sposobów kontraktowania towarzyszą dysfunkcje i nieefektywność [Sprawozdanie ₹ driałalności..., 2015]. Wymienione rodzaje alokacji zapewniają bowiem różne poziomy zabezpieczenia wymaganych standardów i generują różny poziom kosztów. Jest to kwestia, którą należy zinterpretować jako problem wyboru

\footnotetext{
${ }^{1} \mathrm{~W}$ artykule używa się określenia podmioty leczniczęe na oznaczenie podmiotów wykenujacych dz̨iałalność lecznicza, tj.: przedsiębiorców, samodzielnych publicznych zakładów opieki zdrowotnej, jednostek budżetowych i instytutów badawczych. Funkcjonowanie podmiotów wykonujących działalność leczniczą wyznacza znowelizowana w 2015 roku Ustawa o driatalności lečničej z dnia 15 kwietnia 2011 roku (Dz. U. 2011, $\mathrm{Nr} 112$, poz. 654).
} 
optymalnej dla tej działalności formy koordynacji, tj. sposobu alokacji przez rynek, organizację lub hybrydy, a zatem problem należący do kluczowych w ekonomii kosztów transakcji (EKT).

Celem artykułu jest przedstawienie z perspektywy ekonomii kosztów transakcji (EKT) uwarunkowań wyboru dotyczącego formy koordynacji (governance mode) dla gospodarowania danymi osobowymi pacjentów w podmiotach leczniczych. Artykuł jest oparty na analizie literatury przedmiotu z zakresu ekonomii kosztów transakcji oraz regulacji i praktyki związanej z przetwarzaniem i ochroną danych osobowych w sektorze podmiotów leczniczych. Opracowanie poszerza dorobek badań z zastosowaniem EKT, włączając do tego dorobku problematykę gospodarowania danymi osobowymi pacjentów we wspomnianym sektorze.

W kolejnych częściach artykułu opisano istotę gospodarowania danymi pacjentów w placówkach leczniczych i określono problem badawczy jako wybór związany z formą koordynacji dla realizacji tej działalności. W świetle EKT zaprezentowano istotę form koordynacji i determinanty ich wyboru. Następnie poddano analizie stosowane w placówkach medycznych formy koordynacji i ich determinanty, stwierdzając częściową niezgodność tych rozwiazań z ustaleniami EKT. W podsumowaniu sformułowano wnioski obejmujące metodykę dalszych badań i praktykę w zakresie wyboru formy alokacji dla gospodarowania danymi pacjentów w analizowanym sektorze.

\section{Istota gospodarowania danymi osobowymi w podmiotach leczniczych i problem sposobu realizacji tej działalności}

Gospodarowanie danymi osobowymi staje się coraz istotniejszym obszarem działalności podmiotów leczniczych. Na działalność tę składają się czynności i zasoby, które służą przetwarzaniu i ochronie danych osobowych. Zgodnie z Ustawa o ochronie danych osobonych z. dnia 29 sierpnia 1997 roku (Dz. U. 1997, Nr 133, poz. 883 z późn. zm.), dane osobowe to wszelkie informacje dotyczące zidentyfikowanej lub możliwej do zidentyfikowania osoby fizycznej. Przetwarzanie danych osobowych jest definiowane w tej ustawie jako: operacje mylkonywane na danych osobonych, takie jak zbieranie, utrwalanie, przechonywanie, opraconywanie, zmienianie, udostepnianie i usuwanie, a zw taszcza te [operacje-prayp. autora], które uyykonije sie w systemach informatycznych [Ustawa o ochronie danych osobouych..., 1997]. Wspomniana ustawa definiuje także zadania i odpowiedzialność administratora danych i administratora bezpieczeństwa informacji jako instytucji i osób bezpośrednio odpowiadających za przetwarzanie i ochronę danych osobowych [Wyka, Nerka, 2012].

Przez ochronę danych osobowych rozumie się ich przetwarzanie zgodne z wymogami Ustany o ochronie danych osobonych, które według art. 36 zabezpiecza dane przed ich udostępnieniem osobom nieupoważnionym, zabraniem przez osobę nieuprawniona, przetwarzaniem z naruszeniem ustawy oraz zmiana, utrata, uszkodzeniem lub zniszczeniem [Ustawa o ochronie danych osobonych..., 1997, art. 36]. Na mocy wymienionej ustawy administrator danych osobowych: 
- $\quad$ stosuje środki techniczne i organizacyjne zapewniajace ochronę przetwarzanych danych osobowych odpowiednią do zagrożeń oraz kategorii danych objętych ochrona;

- zabezpiecza dane przed ich udostępnieniem osobom nieupoważnionym, zabraniem przez osobę nieuprawniona, przetwarzaniem $z$ naruszeniem ustawy oraz zmiana, utrata, uszkodzeniem lub zniszczeniem;

- prowadzi dokumentację opisująca sposób przetwarzania danych oraz odpowiednie środki techniczne i organizacyjne.

Z kolei, administrator bezpieczeństwa informacji:

- nadzoruje dokumentację oraz procesy i procedury bezpiecznego gospodarowania danymi osobowymi;

- dokonuje sprawdzeń i w ich wyniku wdraża działania korekcyjne, korygujące bądź zachowawcze;

- prowadzi szkolenia aktualizacyjne dla osób przetwarzających dane osobowe.

Określone w regulacjach czynności i odpowiedzialność w zakresie przetwarzania i ochrony danych osobowych pacjentów determinują istotę gospodarowania danymi osobowymi, choć nie wyczerpuja jego natury jako kategorii ekonomicznej. W sensie ekonomicznym, gospodarowanie danymi osobowymi obejmuje czynności i zasoby potrzebne do przetwarzania i ochrony tych danych, tj. do ich wytworzenia i wykorzystywania, w celu zaspokojenia określonych potrzeb (osiagnięcia określonej użyteczności). Do wspomnianych czynności i zasobów z nimi powiązanych należą:

- utrzymanie oraz rozwój materialnej i niematerialnej infrastruktury obejmującej przetwarzanie i ochronę danych osobowych (infrastruktury informatycznej i oprogramowania);

- $\quad$ tworzenie, aktualizacja oraz rozwój formalno-prawnych i organizacyjnych zasad dotyczących działalności w tej dziedzinie (opracowywanie regulaminów i procedur, układu hierarchii organizacyjnej i struktury nadzoru nad przetwarzaniem danych osobowych);

- $\quad$ kontraktowanie i nadzór nad personelem odpowiedzialnym za przetwarzanie danych osobowych;

- bieżące czynności operacyjne w zakresie przetwarzania danych osobowych;

- doskonalenie działań i zasobów (szkolenia i doradztwo w zakresie przetwarzania i ochrony danych osobowych).

Biorąc pod uwagę zakres wymienionych czynności, ten obszar działalności podmiotów leczniczych generuje wysokie koszty. Perspektywa ich dodatkowego wzrostu wynika z nowej dyrektywy Unii Europejskiej dotyczącej ochrony danych osobowych, która zacznie obowiązywać od 25 maja 2018 roku [Dyrektywa Parlamentu Europejskiego $i$ Rady (UE)..., 2016]. Obowiązek prowadzenia dokumentacji medycznej wyłącznie w formie elektronicznej, zatrudnienia inspektora do spraw ochrony danych osobowych, prawo do prywatności oraz do „bycia zapomnianym” wymuszą szereg zmian w funkcjonowaniu podmiotów prowadzących działalność leczniczą. Wykorzystując systemy informatyczne, podmiot leczniczy musi spełnić wysokie wymagania: technologiczne, prawne i nadzorcze [Banyś, Łuczak, 2014, s. 213]. Tradycyjne przetwarzanie danych osobowych jest 
z reguły tańsze i prostsze, nie wymaga bowiem technologicznie zaawansowanej infrastruktury i skomplikowanej obsługi.

Ze względu na naturę tej działalności, korzyści są mierzone nie zyskiem, lecz osiagnięciem użyteczności wynikającej z realizacji takich potrzeb, jak:

- $\quad$ dostępność danych (zapewnienie dostępu do danych w czasie, w którym sa one potrzebne);

- $\quad$ kompletność danych (zagwarantowanie danych adekwatnych do podjęcia decyzji przez lekarza, tj. wystarczających, ale niewykraczających poza zakres niezbędny dla tej decyzji);

- poufność przetwarzanych danych (ochrona danych przed nieupoważnionym użytkowaniem, wyciekiem dla celów komercyjnych, niezgodnych z interesem pacjenta itd.);

- zapewnienie integralności danych w różnych systemach, umożliwiające ich jednoznaczną prezentację na potrzeby: badania, diagnozy, wyboru terapii i określenia możliwości jej finansowania;

- zagwarantowanie rozliczalności danych, czyli możliwość jednoznacznego zidentyfikowania osoby przetwarzającej określone dane osobowe.

Przetwarzanie i ochrona danych osobowych stanowią integralny element świadczenia leczniczego, które opiera się na informacji o pacjencie. Jednocześnie, w wyniku usługi medycznej, sa tworzone nowe dane dotyczace: stanu zdrowia, przebiegu leczenia, kodu genetycznego i innych wrażliwych cech osób korzystających z tej usługi. Nieuprawnione udostępniane danych grozi: postępowaniem cywilnym, administracyjnym i karnym oraz utratą reputacji. Odpowiedzialność podmiotów leczniczych, będących przedsiębiorcami, jest zależna od formy prowadzonej przez nie działalności [GregoHoffmann, 2013]. Ponoszą one zarówno odpowiedzialność deliktowa, jak i kontraktowa, w zależności od tego, czy wiąże je umowa z poszkodowanym, czy też nie [agielski, 2010; Nowakowski, Jędruszczak, Gałach, 2013].

Działalność w zakresie przetwarzania i ochrony danych osobowych podlega rozbudowanym regulacjom prawnym. Dotychczas obowiązujace regulacje prawne na szczeblu Unii Europejskiej, do których odnosi się ustawodawstwo polskie, zawarte są w Dyrektywie 95/46/WE Parlamentu Europejskiego $i$ Rady z dnia 24 paźdriernika 1995 roku w sprawie ocbrony osób fisycznych w zakeresie przetwarzania danych osobowych i swobodnego przeptywu danych [Barta i in. 2014; Barta, Litwiński, 2015]. Obowiązek dokumentacyjny w tej dziedzinie zawiera z kolei Rozporzadzenie Ministra Spraw Wewnetrznych i Administracji z dnia 29 kewietnia 2004 roku w sprawie dokumentacjiprzetwarzania danych osobowych oraz warunkón technicznych i organizacyjnych, jakim powinny odpowiadać urzadzenia i systemy informatyczne stużace do przetwarzania danych osobowych (Dz. U. z 2004 roku, Nr 100, poz. 1024). Ponadto, funkcjonowanie administratora bezpieczeństwa informacji regulują rozporządzenia w sprawie: wzorów zgłoszeń (Dz. U. z 2014, poz. 1934), sposobu prowadzenia rejestru zbioru danych (Dz. U. z 2015, poz. 719) oraz trybu i realizacji zadań (Dz. U. z 2015, poz. 745).

Dążąc do osiagnięcia użyteczności, tj. zrealizowania wymienionych wcześniej potrzeb związanych z przetwarzaniem i ochroną danych osobowych, podmioty lecznicze przyjmują różne formy koordynacji celem gospodarowania w tej dziedzinie. Czynności te 
bywają wykonywane tak samodzielnie, jak i w drodze zewnętrznych kontraktów, do których należą: umowa ramowa (formalny kontrakt długoterminowy), kontrakty relacyjne (powtarzalne zlecenia) czy usługi nabywane na rynku. Zauważa się także łączenie wymienionych form koordynacji oraz częste zmiany i przekształcenia w obrębie już zastosowanych rozwiązań. Obserwuje się zatem proces swoistego eksperymentowania podmiotów leczniczych z odmiennymi wariantami koordynacji działalności w zakresie przetwarzania i ochrony danych osobowych. Liczne procesy sądowe związane z niewłaściwym przetwarzaniem danych w Polsce i innych krajach Unii Europejskiej oraz dotychczasowe doświadczenia podmiotów leczniczych, obejmujące koszty i dysfunkcje systemów przetwarzania danych osobowych, wskazują na istotny problem dotyczący sposobu realizacji tego obszaru działalności [Sprawozdanie z. driałalności..., 2015].

Problem ten odnosi się do rozstrzygnięcia, w jakim stopniu gospodarowanie danymi osobowymi pacjentów powinno być realizowane samodzielnie przez podmiot leczniczy (zinternalizowane), a w jakim dzięki zewnętrznemu kontraktowaniu na zasadzie długoterminowych kontraktów lub transakcji rynkowych.

\section{Formy koordynacji i czynniki ich wyboru w ujęciu ekonomii kosztów transakcji}

Na sformułowany powyżej problem odpowiada ekonomia kosztów transakcji, traktowana jako główny nurt nowej ekonomii instytucjonalnej (NEI).W ujęciu EKT, mamy do czynienia z potrzebą wyboru struktury/formy koordynacji ${ }^{2}$ (governance structure, governance mode, form of governance) dla gospodarowania danymi osobowymi w podmiotach leczniczych, w sytuacji określonych wymagań regulacyjnych.

Aspekt otoczenia regulacyjnego (instytucjonalnego) każe odwołać się również do szerszych założeń nowej ekonomii instytucjonalnej, koncentrującej się na instytucjach jako wyznacznikach i ograniczeniach dla działalności podmiotów gospodarujących [Zą̧bowicz, 2003; Klimczak, 2006]. W szerokim znaczeniu, instytucje to zespoły zarówno formalnych zasad, jak i nieformalnych norm, które wpływają na zachowania ludzi i nadają porządek ich działaniu [North, 1990; Gancarczyk, 2002; Gruszewska, 2012]. Przy czym przedmiotem zainteresowania NEI sa przede wszystkim instytucje o charakterze formalnym [Gorynia, 1999].

Wyróżnia się zazwyczaj dwa obszary badawcze i dwa rodzaje instytucji rozważanych w NEI [Williamson, 1998; 2005; Mènard, Shirley, 2005, s. 345]. Obszar badania instytucji koordynacji (governance structures, institutions of governance) i instytucji nadzoru nad kontraktami jest reprezentowany przez ekonomię kosztów transakcji i teorię agencji. Ekonomia kosztów transakcji szczególnie koncentruje się na instytucjach koordynacji jako sposobach regulowania wymiany gospodarczej, do których zalicza się firmę, rynek i struktury pośrednie (hybrydy), takie jak: formalny kontrakt długoterminowy, kontrakty relacyjne czy joint venture. Nadzór i bodźce do efektywności w realizacji kontraktów głównie są rozważane w teorii agencji.

\footnotetext{
${ }^{2}$ Określenia: struktura koordynacji i forma koordynacji są w artykule stosowane zamiennie.
} 
Z kolei, obszar badania otoczenia instytucjonalnego (institutional environment), tj. przede wszystkim formalnych regulacji prawnych wpływających na poziom kosztów transakcji, rozwijany jest w teorii praw własności i teorii wyboru publicznego.

Biorąc pod uwagę rozważany problem, wybór formy koordynacji dla gospodarowania danymi osobowymi powinien uwzględniać oba rodzaje instytucji. Otoczenie instytucjonalne należy traktować jako zespół reguł, który zasadniczo nie podlega oddziaływaniu podmiotów leczniczych, lecz musi być przez nie wykorzystywany w wyborze formy koordynacji. Determinuje ono zwłaszcza potrzeby, na które powinno odpowiadać gospodarowanie danymi osobowymi pacjentów, tj. oczekiwaną użyteczność, jak przedstawiono to w punkcie drugim. Przedmiotem decyzji dokonywanych przez podmioty lecznicze są natomiast struktury koordynacji. Podstawą teoretyczną i metodyczną tego rodzaju wyborów są założenia ekonomii kosztów transakcji dotyczące cech poszczególnych struktur. W tej sytuacji należy poddać analizie cechy i determinanty wyboru form koordynacji z perspektywy EKT.

Według O.E. Williamsona, istnieje wzajemna zależność między formą koordynacji a kosztami transakcyjnymi. Zgodnie z EKT, koszty transakcji ${ }^{3}$ to względne koszty realizacji określonej działalności w różnych strukturach koordynacji, tj. poprzez: rynek, firmę lub formy pośrednie (hybrydy) (ex ante i ex post, tj. przed i po zawarciu kontraktu) [Williamson, 1979; 1989, s. 142]. W tej definicji działalność jest utożsamiana z transakcją gdyż każdą czynność (działanie) interpretuje się w kategoriach wymiany i kontraktowania [Hardt, 2009].

Zgodnie z hipoteza dopasowania (discriminatingalignment hypothesis) Williamsona, do transakcji, które różnią się atrybutami, dopasowywane są formy koordynacji, te natomiast różnią się kosztami i korzyściami, co prowadzi do oszczędności na kosztach transakcji [Williamson, 1991; 2005]. Decyzje te są podejmowane w warunkach ograniczonej racjonalności i oportunizmu. Zgodnie z ograniczoną racjonalnością, podmioty gospodarujące dążą do decyzji racjonalnych, ale cel ten nie jest w pełni osiągany ze względu na ograniczenia poznawcze. Ponadto, przyjmuje się założenie o oportunistycznych motywach partnerów wymiany, którzy realizują swoje interesy przy użyciu podstępu, np. podając niepełną lub fałszywą informację [Williamson, 1973]. Niepełna wiedza i ograniczona racjonalność powodują że w pełni nie można doprecyzować warunków umów, które zawsze pozostają niekompletne, prowokując oportunizm.

Wybór formy koordynacji odbywa się dzięki porównawczej analizie korzyści i kosztów transakcyjnych różnych wariantów tych form. Kryteriami (determinantami) doboru form, celem realizacji danej działalności, są cechy transakcji, do których należą: specyfika aktywów, częstotliwość i niepewność [Williamson, 1985; 1998]. Aktywa specyficzne to inwestycje na potrzeby określonej wymiany, lokowane w zasoby i umiejętności, które

\footnotetext{
${ }^{3}$ Koszt transakcji jest koncepcją i pojęciem stosowanym w różnych obszarach badawczych NEI i stąd rozmaicie definiowanym. Występują zatem [Gancarczyk, 2006]: 1) koszty związane z negocjowaniem i zawieraniem kontraktu na rynku [Coase, 1937]; 2) koszty ponoszone podczas dokonywania zamiany praw własności na aktywa i egzekwowania praw do wyłączności korzystania z tych aktywów [Eggertson, 1990]; 3) koszty wynikające z: przekazywania, przejmowania i ochrony praw własności [Barzel, 1997]; 4) koszty funkcjonowania systemu gospodarczego [Arrow, 1974, s. 48]; 5) koszty wykorzystywania zasobów potrzebnych do wymiany praw własności poprzez rynek [Kasper, Streit, Manfred, 1998; Kasper, Streit, Boettke, 2012].
} 
tracą na wartości w sytuacji alternatywnego zastosowania. Do przykładów specyficzności należą: lokalizacja inwestycji w pobliżu kooperanta, dostosowanie umiejętności personelu, infrastruktury (sprzętu, wyposażenia, technologii), systemu marketingowego lub harmonogramu operacji (np. dostaw). Częstotliwość dotyczy liczby transakcji w jednostce czasu [Williamson, 1991]. Niepewność wynika z założenia o oportunizmie partnera wymiany oraz z nieprzewidywalności otoczenia [Williamson, 1973; Gancarczyk, 2015]. W przypadku wysokiej specyficzności aktywów zazwyczaj rośnie częstotliwość transakcji z określonym partnerem. Inwestycje w aktywa powodują zależność stron wymiany. Jeśli inwestycje te sa proporcjonalnie rozłożone między kooperantów, mogą być traktowane jako gwarancja wiarygodnych zobowiązań. Większe inwestycje jednej ze stron kontraktu prowokuja jednak oportunizm partnera mniej zależnego [Klein, Crawford, Alchian, 1978]. Specyficzność aktywów zwiększa wówczas niepewność związaną z oportunizmem. Oportunizm z kolei wywołuje zarówno koszty związane z potrzebą zabezpieczeń (np.: zapisy w kontraktach, nadzór i kontrola), jak i koszty nieprzestrzegania kontraktu [Gancarczyk, 2015]. Biorąc pod uwagę analizowane zależności między atrybutami transakcji, za główną determinantę należy uznać specyficzność aktywów, gdyż wpływa ona na pozostałe czynniki, zwłaszcza oportunizm, przyczyniając się w rezultacie do wzrostu kosztów transakcji.

Relacje między charakterystyką determinant transakcji a formami koordynacji można przedstawić jak poniżej.

1. Wysoki poziom specyficzności aktywów powoduje wzrost kosztów transakcji, który prowadzi do decyzji o internalizacji i wycofaniu się z transakcji rynkowych czy też długoterminowych kontraktów formalnych bądź relacyjnych. Zamiast nabywać aktywa na rynku albo dzięki współpracy (hybrydy), organizacja wytwarza je samodzielnie.

2. Gdy wysokiej specyficzności towarzyszy niska częstotliwość, dopuszczalne są struktury hybrydowe, ponieważ koszty internalizacji w pełni nie znajdują uzasadnienia.

3. W przypadku przeciętnej specyficzności aktywów zazwyczaj są zalecane rozwiązania hybrydowe w postaci kooperacji na podstawie kontraktu długoterminowego lub kontraktów relacyjnych, tj. powtarzalnych zleceń, bez formalnej umowy ramowej.

4. Wysoka częstotliwość i/lub niepewność transakcji z wykorzystaniem przeciętnie specyficznych aktywów stanowią przesłanki dla internalizacji danej działalności.

5. Wysoka niepewność może także być uzasadnieniem rezygnacji z aktywów specyficznych na rzecz niespecyficznych i powszechnie dostępnych na rynku, co stanowiłoby podstawę do zastosowania transakcji rynkowych.

6. W sytuacji niskiej specyficzności aktywów generalnie zaleca się transakcje rynkowe, niezależnie od stopnia niepewności i częstotliwości [Williamson, 1985, 1998; Gorynia, 1999].

Ekonomia kosztów transakcji proponuje zatem kryteria doboru form koordynacji, w celu zaoszczędzenia na kosztach transakcji, jak również analizę porównawczą poszczególnych form. Przyjmuje się więc założenie, że zgodnie z teoria, dopasowanie formy 
koordynacji do charakterystyki tych czynników zapewnia oszczędności na kosztach transakcji. Porównanie teoretycznych założeń z praktyką stało się przyczyną weryfikacji EKT w licznych badaniach empirycznych i pracach przeglądowych [Gancarczyk, 2015]. Zazwyczaj studia te zmierzały także do stwierdzenia, w jaki sposób zgodność lub niezgodność z teorią łączyła się z efektywnością danej formy koordynacji. Tego rodzaju badania przynosiły tak weryfikację teorii, jak i wiedzę na temat kryteriów wyboru efektywnych form koordynacji stosowanych w praktyce. Obok determinant typowych dla EKT, często wskazywano wśród tych czynników kompetencje i zasoby danej organizacji, w tym zdolności koordynacyjne (zdolności do koordynacji transakcji w różnych strukturach) [David, Han, 2004].

\section{Formy koordynacji dla gospodarowania danymi osobowymi w podmiotach leczniczych i kryteria ich wyboru}

Powyższe rozważania umożliwiają sformułowanie założenia o wyborze optymalnej formy koordynacji dla gospodarowania danymi osobowymi w podmiotach leczniczych. W tej dziedzinie optymalna będzie struktura, która zapewni osiagnięcie wymaganej użyteczności (realizacji potrzeb wymienionych w punkcie drugim przy najniższych kosztach transakcyjnych.

W ślad za wcześniej przedstawioną teorią przyjęto, że w ramach określonych wymagań prawnych, forma koordynacji dla gospodarowania danymi osobowymi w podmiotach leczniczych powinna być dopasowana do cech transakcji, tj.: specyficzności aktywów, częstotliwości i niepewności związanej z zachowaniem partnera wymiany (oportunizmem) oraz zmiennością otoczenia. Jednocześnie podjęto analizę porównawczą form koordynacji wykorzystywanych w podmiotach leczniczych dla gospodarowania danymi osobowymi pacjentów.

Jako metody badawcze zostały wykorzystane analiza źródeł wtórnych dotyczących funkcjonowania podmiotów leczniczych i obserwacja uczestnicząca. Druga z wymienionych metod stanowi źródło informacji pierwotnych, gdyż autor opracowania zdobył wieloletnie doświadczenie jako konsultant w sektorze podmiotów leczniczych.

Zgodnie $\mathrm{z}$ rozważaniami $\mathrm{w}$ punkcie drugim, gospodarowanie danymi osobowymi obejmuje zespół czynności (działań). Każda z tych czynności może zostać potraktowana jako indywidualna transakcja, wymagająca decyzji co do alokacji rynkowej w ramach organizacji czy też $\mathrm{w}$ formie struktur pośrednich, takich jak formalny kontrakt długoterminowy (umowa ramowa) lub kontrakty relacyjne (powtarzalne kontrakty rynkowe, nieuregulowane umowa ramowa). W kolejnych punktach przeprowadzono analizę czynności, które należą do gospodarowania danymi osobowymi (por. punkt 2.), z wykorzystaniem przedstawionych założeń metodycznych.

1. Utrzymanie i rozwój materialnej i niematerialnej infrastruktury celem bezpiecznego przetwarzania danych osobowych (szczególnie infrastruktury informatycznej - sprzętu i oprogramowania). 
Gromadzenie i przetwarzanie informacji o pacjencie wymagaja integracji danych pochodzących z różnych urządzeń medycznych, z których każde funkcjonuje według indywidualnych standardów producenta. W praktyce obserwuje się różne poziomy specyficzności infrastruktury informatycznej potrzebnej do integracji danych.

Wysoki poziom specyficzności charakteryzuje podmioty o szerokim zakresie usług medycznych, które wykorzystują zaawansowane systemy integracji danych. Stosownym rozwiązaniem jest wówczas rozwój platformy informatycznej, specjalnie na potrzeby własne operacji [Szymczyk, Horoch, 2013, s. 321]. Platforma taka stanowi zasób wysoce specyficzny, którego aktualizacja i serwisowanie wymaga przeciętnej częstotliwości związanej z istotnymi zmianami regulacyjnymi i zmianami wewnątrz samej organizacji. Najczęściej stosowaną formą koordynacji tej działalności jest umowa długoterminowa lub kontrakty relacyjne z firmą informatyczną (forma hybrydyczna). Jednocześnie, ze względu na częsty brak specjalistycznych kompetencji w organizacji, dochodzi do silnego uzależnienia od dostawców takich usług, co sugeruje zastosowanie integracji pionowej i internalizacji działalności wewnątrz podmiotu leczniczego (wysoka specyficzność i wysoka niepewność związana z oportunizmem partnera kontraktu oraz burzliwym rozwojem technologii i regulacji prawnych). W większości przypadków unika się jednak internalizacji i pozostaje przy kontrakcie długoterminowym lub relacyjnym, a to powoduje koszty transakcyjne związane z oportunizmem kooperanta. Innym rozwiązaniem jest rezygnacja z rozwijania niezbędnego oprogramowania, działającego w ramach zintegrowanej platformy informatycznej, na rzecz działania w różnych systemach przetwarzania danych [Kautsch, Poznański, 2009, s. 54]. Rozwiązanie to często jest obarczone błędami i nie spełnia wymaganych standardów [Szymczyk, Horoch, 2013, s. 321]. W skrajnych przypadkach, aby zmniejszyć stopień złożoności pozyskiwania i przetwarzania danych, podmiot leczniczy rezygnuje z wykorzystywania określonej aparatury, co obniża standard usługi medycznej [Sprawozdanie z.działalności..., 2015].

Niski poziom specyficzności aktywów dla rozważanych działań cechuje podmioty lecznicze o waskim zakresie oferowanych świadczeń leczniczych. Złożoność procesów i procedur, dotyczacych przetwarzania danych osobowych, jest tu zdecydowanie niższa oraz dominuje zakup powszechnie dostępnej infrastruktury informatycznej i usług na rynku. Rozwiązania te zazwyczaj są efektywne kosztowo i oferują stosowny poziom użyteczności, tj. realizacji potrzeb związanych z przetwarzaniem danych osobowych. Szacuje się, iż w 90\% przypadków zastosowania technologii informatycznych w opiece zdrowotnej odnotowano wzrost oszczędności i efektywności zarówno w szpitalach, jak i opiece ambulatoryjnej [Chojnacki, Gastecka, 2014, s. 181]. Stosunkowo niskiej specyficzności wymaganych aktywów rozwiazań towarzyszy przeciętna częstotliwość i przeciętny poziom niepewności (małe zagrożenie oportunizmem usługodaw- 
cy, choć dość znaczna burzliwość otoczenia - zmienność technologii i regulacji). W tym przypadku obserwuje się zgodność z założeniami EKT w zakresie hipotezy dopasowania.

2. Tworzenie, aktualizacja i rozwój formalno-prawnych i organizacyjnych zasad dotyczących działalności w tej dziedzinie (m.in. opracowywanie regulaminów i procedur, układu hierarchii organizacyjnej i struktury nadzoru nad przetwarzaniem danych osobowych).

Podobnie jak w przypadku pierwszej grupy czynności, można zauważyć różne struktury koordynacji w podmiotach leczniczych o odmiennym zakresie usług.

Podmioty lecznicze o szerokim zakresie świadczeń leczniczych i dużej złożoności operacji same w większości opracowują wewnętrzne procedury jakości w obszarze bezpieczeństwa przetwarzanych danych osobowych. Działalność ta podlega zatem internalizacji, co znajduje uzasadnienie w wysokiej specyficzności występujących tu aktywów. Złożoność funkcjonowania nie pozwala bowiem na powielanie standardów dostępnych na rynku, ale wymaga rozwoju specjalistycznej wiedzy o organizacji, aby opracować dokumentację na potrzeby określonej jednostki. Częstotliwość transakcji pozostaje stosunkowo niska, gdyż raz opracowana dokumentacja zachowuje aktualność w dłuższym okresie i wymaga jedynie dostosowań. Zlecanie tej specyficznej działalności na zewnątrz grozi znacznym uzależnieniem od zleceniobiorcy i podnosi niepewność, która już jest duża ze względu na burzliwość regulacyjną. Dominująca struktura koordynacji jest zgodna z założeniami EKT (wysoka specyficzność i niepewność, przy niskiej częstotliwości) i w praktyce można ją uznać ze rozwiązanie efektywne. Zdarza się również zlecanie opracowania dokumentacji na zewnątrz za sprawą kontraktów o charakterze rynkowym. Zazwyczaj zakres zlecenia obejmuje wdrożenie dokumentacji oraz przeszkolenie osoby lub osób $\mathrm{z}$ organizacji $\mathrm{w}$ dalszym zarządzania bezpieczeństwem przetwarzania danych osobowych. Nabywanie tych usług na zasadach rynkowych jest spowodowane brakiem stosownej wiedzy na temat regulacji i zwiazzana $z$ tym obawa przed naruszeniem zasad bezpieczeństwa danych [Banyś, Łuczak, 2014, s. 183]. Rozwiązania rynkowe są niezgodne z założeniami EKT i grożą kosztami transakcji wobec potencjalnego oportunizmu zleceniobiorcy. Można je uznać za uzasadnione w sytuacji braku odpowiednich kompetencji w organizacji i przy założeniu, że stanowią formę przejściową przed ostateczną internalizacją tej czynności.

Podmioty lecznicze o wąskim zakresie usług medycznych i niewielkiej złożoności operacji często zlecają opracowanie dokumentacji oraz procedur ochrony danych osobowych, a nierzadko także ich nadzorowanie, na zasadach rynkowych. Opracowanie tego rodzaju dokumentacji i nadzór nad procedurami nie wymagają rozwoju specyficznych kompetencji ze strony konsultanta, który w tym obszarze posługuje się ogólną wiedzą na temat branży i regulacji prawnych. Częstotliwość transakcji pozostaje niska, jak wyjaśniono powyżej, a niepewność 
umiarkowana ze względu na niski oportunizm kooperanta, ale znaczną burzliwość regulacji. Powszechnie stosowana struktura koordynacji w postaci kontraktów rynkowych jest zgodna z cechami transakcji (niska specyficzność, niska częstotliwość i umiarkowana niepewność) i w praktyce można ją uznać za efektywna.

3. Kontraktowanie i nadzór nad personelem odpowiedzialnym za przetwarzanie danych osobowych (zatrudnienie/powołanie administratora bezpieczeństwa informacii).

Do 31 grudnia 2014 roku podmiot leczniczy, który w świetle regulacji prawnych jest administratorem danych osobowych, miał obowiązek powołać administratora bezpieczeństwa informacji. Wymóg ten dotyczył wszystkich podmiotów wykonujących działalność leczniczą, niezależnie od rodzaju i zakresu świadczeń leczniczych oraz przetwarzanych danych osobowych. Od 1 stycznia 2015 roku obowiazek został zmieniony w uprawnienie, przy czym obserwuje się różne podejścia do realizacji tej funkcji, w zależności od zakresu działalności podmiotów leczniczych.

Duże podmioty lecznicze o wysokiej złożoności procesów i procedur zazwyczaj powołują a dministratora bezpieczeństwa informacji spośród swoich pracowników. Jest to związane z wysoką specyficznością wiedzy potrzebnej do pełnienia tej funkcji i znaczną niepewnościa. Niepewność wynika z zagrożenia oportunizmem zewnętrznego dostawcy, który uzależniłby podmiot leczniczy od swoich kompetencji, uzyskując nadmierny wpływ na jego działalność. Częstotliwość analizowanej transakcji jest wysoka, gdyż nadzór nad bezpieczeństwem informacji ma charakter ciagły. Internalizacja tej czynności jest uzasadniona z punktu widzenia EKT (wysoka specyficzność, niepewność i częstotliwość) i w praktyce nie budzi zastrzeżeń pod względem efektywności.

Podmioty lecznicze o wąskim zakresie usług, w których nie obserwuje się wysokiej złożoności operacji, zazwyczaj ustanawiaja osobne stanowisko administratora bezpieczeństwa informacji lub rozdzielaja jego obowiązki na kilku pracowników. Wiedza wymagana do nadzoru nad bezpieczeństwem danych osobowych pozostaje na przeciętnym poziomie specyficzności. Znajomość operacji małych podmiotów leczniczych jest upowszechniona w środowiskach dostawców usług dla tego sektora i nie wymaga tak znacznych dostosowań, jak w przypadku podmiotów o złożonej działalności, choć do bieżącego nadzoru potrzeba zdobycia zasobu wiedzy o działaniach typowych dla danej organizacji. Częstotliwość i niepewność tej transakcji pozostają wysokie, z przyczyn jakie wskazano poprzednio dla podmiotów o szerszym zakresie usług. Dominująca w tej działalności internalizacja stanowi rozwiązanie zgodne $\mathrm{z}$ rozważana teoriąi i można je uznać za efektywne.

4. Bieżące czynności operacyjne w zakresie przetwarzania danych osobowych.

Działalność operacyjna osób przetwarzających dane osobowe pacjentów (w większości lekarzy i pielęgniarek) pozostaje w ścisłym związku z samą usługą medyczna, stanowiąc jej integralną część. Podmioty lecznicze stosują w umowach z personelem medycznym zarówno kontrakty outsourcingowe 
(formy hybrydyczne), jak i umowy o pracę (internalizację w ramach hierarchii organizacji). Jednak przy wyborze struktury koordynacji decydujące są cechy usługi medycznej, a nie samych czynności związanych z przetwarzaniem informacji o pacjencie [Saryusz-Wolska, Wronka, 2013, s. 10]. W tej sytuacji forma kontraktowania personelu medycznego nie będzie przedmiotem analizy.

Mimo to można rozpatrywać uzasadnienie stosowanych dość powszechnie umów outsourcingowych (hybryd) i internalizacji w dziedzinie raportowania danych dla Narodowego Funduszu Zdrowia (NFZ). Podobnie jak we wcześniejszych przypadkach, zastosowanie tych form koordynacji wiąże się z odmiennymi cechami podmiotów leczniczych [Grego-Hoffmann, 2013, s. 189].

Outsourcing dotyczy najczęściej podmiotów o wąskim zakresie usług i niewielkiej złożoności działania. Transakcje w zakresie raportowania danych charakteryzują się wówczas niską specyficznością wiedzy potrzebnej do realizacji usługi. Znajomość operacji małych podmiotów leczniczych jest upowszechniona, a ten sam program do raportowania dotyczy wszystkich podmiotów w ramach określonego oddziału NFZ. Mimo wysokiej częstotliwości, niepewność (uzależnienie i potencjalny oportunizm dostawcy usługi) należy w tej sytuacji uznać za niską. Takie połączenie cech transakcji, według EKT, pozwala na zastosowanie outsourcingu $\mathrm{i}$ w praktyce rozwiazanie to można uznać za efektywne.

Z kolei, podmioty lecznicze o szerokim zakresie usług wymagają wysokiej specyficzności wiedzy do raportowania swej działalności. Ze względu na potencjalne uzależnienie i oportunizm dostawcy oraz wysoką częstotliwość rozpatrywanych czynności dokonują ich internalizacji. Postępują wówczas zgodnie z założeniami EKT i osiagają w tej dziedzinie efektywność.

5. Doskonalenie działań i zasobów (szkolenia i doradztwo w zakresie przetwarzania i ochrony danych osobowych).

Szkolenia zwiazane ze zmianami w ustawodawstwie oraz zasadami bezpieczeństwa przetwarzanych danych osobowych sa prowadzone przez administratora bezpieczeństwa informacji lub wyznaczone osoby. Jak wspomniano wcześniej, funkcja administratora bezpieczeństwa informacji jest zazwyczaj internalizowana (por. punkt 3.). Podobnie, w przypadku wysokiej specyfiki aktywów oraz częstotliwości działan, internalizuje się doradztwo związane z bezpiecznym przetwarzaniem danych. Jeśli wymienione warunki nie zachodza, dokonuje się zleceń zewnętrznym podmiotom. To podejście jest zgodne z założeniami EKT i w praktyce efektywne.

\section{Podsumowanie}

W artykule skoncentrowano się na problemie wyboru dotyczącego formy koordynacji dla gospodarowania danymi osobowymi w podmiotach leczniczych. W analizowanym sektorze ta pomocnicza działalność jest obecnie wykonywana w zróżnicowanych formach koordynacji. Zdarza się, że zróżnicowanie struktur łączy się z dysfunkcjami w systemie 
przetwarzania i ochrony danych osobowych oraz kosztami wynikającymi z naruszeń prawa i postępowań sądowych [Sprawozdanie z dziatalności..., 2015]. Jako punkt wyjścia do identyfikacji efektywnych struktur przyjęto założenia ekonomii kosztów transakcji. W wyniku przeprowadzonej analizy można sformułować poniższe wnioski.

1. Formy koordynacji gospodarowania danymi osobowymi pacjentów w podmiotach leczniczych wykazują zróżnicowanie, które obejmuje nie tylko odmienne struktury dla poszczególnych działań należących do gospodarowania w tej sferze. Różnorodne rozwiązania są także stosowane w odniesieniu do tych samych czynności.

2. Nie wszystkie rozwiązania są efektywne pod względem relacji między oczekiwaną użytecznością a kosztami. Rozwiązania nieefektywne pokazują niezgodność z założeniami EKT co do związków między formą koordynacji a charakterystyką transakcji. Obserwacja ta potwierdza wcześniejsze badania, w których wykazywano nadmierne koszty struktur dobranych niewłaściwie z uwagi na EKT [Masten, Meehan, Snyder, 1991].

3. Obok charakterystyki transakcji (specyficzność, częstotliwość, niepewność), istotnym czynnikiem różnicującym wybór formy koordynacji jest zakres świadczonych usług, który implikuje złożoność działalności danego podmiotu leczniczego i jego rozmiar. Cechy te należą do charakterystyki zasobów firmy, a nie do cech transacji rozważanych w EKT. Wpływ zasobów na wybór form koordynacji i granice firmy szeroko dokumentuje się za pomocą badań empirycznych [David, Han, 2004] i odzwierciedla również w teorii, m.in. w poglądach samego O. E. Williamsona [1998]. Wyniki dotychczasowych badań świadczą o potrzebie integracji EKT z podejściem zasobowym w decyzjach dotyczących granic organizacji. Pogląd ten jest istotny zarówno dla praktyki decydentów w sektorze podmiotów leczniczych, jak i dla dalszych badań empirycznych w tej dziedzinie. Wykorzystując główne zmienne EKT do określenia struktur koordynacji $\mathrm{w}$ analizowanym sektorze, należy w przyszłych badaniach uwzględnić takie zmienne kontrolne, jak: rozmiar organizacji, zakres jej działania (poziom dywersyfikacji produktów i usług) czy forma własności (publiczne i niepubliczne podmioty lecznicze).

4. Zgodnie z wcześniejszymi badaniami, istotnym elementem zasobowym w wyborach struktur koordynacji jest tzw. zdolność koordynacyjna (governance capabilities), tj. zdolność do kształtowania kooperacji [Madhok, 2002]. Zdolność ta może pozwolić na wybór zewnętrznego kontraktowania, zamiast internalizacji, nawet w sytuacji wysokiej specyficzności, częstotliwości i/lub niepewności. W omawianym sektorze zdolności te są szczególnie ograniczone ze względu na rzadkość kompetencji menedżerskich w strukturach podmiotów leczniczych, zdominowanych przez profesjonalistów opieki zdrowotnej. Jednak ten stan zwłaszcza przemawia za ekonomią kosztów transakcji jako podstawą wyjaśnienia wyborów granic działania w podmiotach leczniczych i potraktowania zdolności koordynacyjnych jako zmiennych kontrolnych, a nie głównych determinant. 


\section{Literatura}

Arrow K J., 1974, The limits of organization, Norton, New York.

Banyś T., Luczak J., 2014, Ochrona danych osobonych w praktyce, Prescom, Wrocław.

Barta J., Fajgielski P., Markiewicz R., 2015, Ochrona danych osobonych: komentary, Wolters Kluwer, Warszawa.

Barta P., Litwiński P., 2015, Ustawa o ochronie danych osobonych, Wydawnictwo C.H. Beck, Warszawa.

Barzel Y., 1997, Economic analysis of property rights, Cambridge University Press, Cambridge.

Chojnacki M., Gastecka A., 2014, Informatyzacja opieki zdrowotnej w Polsce jako kierunek poprawy efektywności kosztowej systemu, "Progress in Economic Sciences", $\mathrm{nr} 1$.

Coase R. H., 1937, The nature of the firm, "Economica. New Series", no. 4 (16).

David R., Han S-K., 2004, A systematic assessment of the empirical support for transaction cost economics, "Strategic Management Journal", no. 1.

Dyrektywa Parlamentu Europejskiego i Rady (UE) 2016/680 z dnia 27 kwietnia 2016 roku w sprawie

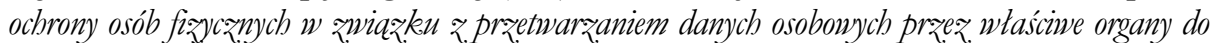
celón zapobiegania przestepczości, prowadzenia postepowan pryygotowawnsych, wykerywania i ścigania caynów zabronionych $i$ wylkomywania kar, w sprawie swobodnego preeptywn takich danych oraz. uchylajaca decysje ramowa Rady 2008/977/WSiSW (Dz. U. L 119 z 04.05.2016).

Eggertson T., 1990, Economic behavior and institutions, Cambridge University Press, Cambridge.

Gancarczyk M., 2002, Instytucja a organizacja w nowej ekonomii instytucjonalnej, „Gospodarka Narodowa", nr 5-6.

Gancarczyk M., 2006, Koszty transakcyjne - teoria i sposób pomiaru, „Ekonomika i Organizacja Przedsiębiorstwa", nr 6.

Gancarczyk M., 2015, Proces wærostu przedsiębiorstwa w świetle podejscia zasobowego i teorii kosztów transakcyjnych, „Gospodarka Narodowa”, nr 5.

Gorynia M., 1999, Przeedsiebiorstwo w nowej ekonomii instytucjonalnej, „Ekonomista”, nr 6.

Grego-Hoffmann M., 2013, Odpowiedzialność podmiotów lecz̨nicsych i personelu medycznego, Prescom, Wrocław.

Gruszewska E., 2012, Transformacja instytucji nieformalnych w Polsce, „Gospodarka Narodowa", nr 3 .

Hardt $Ł ., 2009$, The history of transaction cost economics and its recent developments, "Erasmus Journal for Philosophy and Economics", no. 1.

Jagielski M., 2010, Prawo do ochrony danych osobouych. Standardy europejskie, Wolters Kluwer, Warszawa.

Kasper W., Streit M. E., Boettke P. J., 2012, Institutional economics: Property, competition, policies, Edward Elgar Publishing, Cheltenham.

Kasper W., Streit M. E., Manfred E., 1998, Institutional Economics, Edward Elgar Publishing, Cheltenham.

Kautsch M., Poznański D., 2009, Informatyzacja w zakładach opieki zdrowotnej. Wspótczesne wyzwania menedżerskie w ochronie zdrowia, Wydawnictwo Olsztyńskiej Wyższej Szkoły Informatyki i Zarządzania, Olsztyn. 
Klein B., Crawford R. G., Alchian A. A., 1978, Vertical integration, appropriable rents, and the competitive contracting process, "The Journal of Law \& Economics", no. 2.

Klimczak B., 2006, Wybrane problemy i zastosowania ekonomii instytucjonalnej, Wydawnictwo Akademii Ekonomicznej im. Oskara Langego, Wrocław.

Madhok A., 2002, Reassessing the fundamentals and beyond: Ronald Coase, the transaction cost and resource-based theories of the firm and the institutional structure of production, "Strategic Management Journal", no. 6.

Masten S. E., Meehan J. W. Jr., Snyder E. A., 1991, The costs of organization, "Journal of Law, Economics and Organization", no. 1.

Menard C., Shirley M. M., 2005, Handbook of new institutional economics, Springer, Dordrecht.

Nojszewska E., 2011, System ochrony zdrowia w Polsce, Wolters Kluwer, Warszawa.

North D. C., 1990, Institutions, institutional change and economic performance, Cambridge University Press, Cambridge.

Nowakowski B., Jędruszczak A., Gałach A., 2013, Ochrona danych osobouych, informacji niejawnych $i$ systemów teleinformatycznych w sektorze publicznym, Wydawnictwo C.H. Beck, Warszawa.

Rozporzadzenie Ministra Administracji i Cyfryzacji z.dnia 10 grudnia 2014 r. w sprawie wzorów zgloszeń powolania i odwołania administratora bezpieczeństwa informacji, Dz. U. 2014 poz. 1934.

Rozporzadzenie Ministra Administracji i Cyfryzacii z. dnia 11 maja 2015 r. w sprawie sposobu prowadzenia przez administratora bezpieczeństwa informacij rejestru zbiorów danych, Dz.U. 2015 poz. 719.

Rozporzadzenie Ministra Spraw Wewnetrznych i Administracji zdnia 29 kwietnia 2004 roku w sprawie dokumentacji przetwarzania danych osobowych oraz. warunków technicznych i organizacyjnych, jakim powinny odpowiadać urzadzenia $i$ systemy informatyczne stużce do prz̨etwarzania danych osobowych, Dz. U. z 2004 roku, Nr 100, poz. 1024.

Saryusz-Wolska H., Wronka M., 2013, Efektywność w opiece zdrowotnej- zarys wielowymiarowego problemu w okeresie transformacji, „Studia Ekonomiczne”, nr 168.

Sprawozdanie z. działalności Generalnego Inspektora Ochrony Danych Osobowych w roku 2015, 2015, GIODO, http://www.giodo.gov.pl/data/filemanager_pl/sprawozdaniaroczne/ 2015.pdf (data wejścia: 06.11.2016).

Suchecka J., 2010, Ekonomia zdrowia i opieki zdrowotnej, Wolters Kluwer, Warszawa.

Szymczyk D. M., Horoch A., 2013, Implementacja elektronicznej dokumentacji medycznej. Czesśc 1 - wplyw na efeketywność pracy personelu medycznego, „Medycyna Ogólna i Nauki o Zdrowiu", nr 3.

Ustawa o działalności leczniczej z. dnia 15 kwietnia 2011 roku, Dz. U. 2011, Nr 112, poz. 654. Ustawa o ochronie danych osobowych z. dnia 29 sierpnia 1997 roku, Dz. U. 1997, Nr 133, poz. 883 z późn. zm.

Ustawa z. dnia 28 kwietnia 2011 roku o systemie informacji w ochronie zdrowia, Dz. U. 2011, Nr 113, poz. 657 z późn. zm.)

Ustawa z dnia 5 grudnia 1996 roku o zawodach lekarza i lekarza dentysty, Dz. U. 1997, Nr 28, poz. 152 z późn. zm. 
Williamson O. E., 1973, Markets and hierarchies: some elementary considerations, “The American Economic Review", no. 2.

Williamson O. E., 1989, Transaction cost economics, [in:] Handbook of industrial organization, R. Schmalensee, R. Willig (eds.), vol. 1, Elsevier Science Publishers, Amsterdam.

Williamson O. E., 1991, Comparative economic organization: The analysis of discrete structural alternatives, "Administrative Science Quarterly", no. 2.

Williamson O. E., 1998, Transaction costs economics: How it works, where it is headed, "De Economist", no. 1.

Williamson O. E., 2005, The economics of governance, "The American Economic Review", no. 2 .

Williamson O., 1979, Transaction-cost economics: The governance of contractual relations, "Journal of Law and Economics", no. 2.

Williamson O.E., 1985, The economic institutions of capitalism, The Free Press, New York.

Wyka T., Nerka A., 2012, Ochrona danych osobonych podmiotów objetych prawem pracy i prawem ubeapieczeń spotecznych, Wolters Kluwer Polska, Warszawa.

Ząbkowicz A., 2003, Wspótczesna ekonomia instytucjonalna wobec gtównego nurtu ekonomii, „Ekonomista”, nr 6. 